\title{
ANNOUNCEMENT EFFECT ANOMALY AND ITS DETERMINANTS ON SEASONED EQUITY OFFERINGS: EVIDENCE FROM TURKEY
}

\author{
DOI: 10.17261/Pressacademia.2018.823 \\ JEFA- V.5-ISS.2-2018(3)-p.168-183 \\ Mustafa Cikrikci ${ }^{1}$, Mustafa Ozyesil ${ }^{2}$ \\ ${ }^{1}$ Istanbul Aydin University, Istanbul, Turkey. \\ mustafacikrikci@aydin.edu.tr, ORCID: 0000-0002-2805-6079 \\ 2 Istanbul Aydin University, Istanbul, Turkey. \\ mozyesil@aydin.edu.tr, ORCID: 0000-0002-4442-7087
}

To cite this document

Cikrikci, M., Ozyesil, M. (2018). Announcement effect anomaly and its factors on seasoned equity offerings: evidence from Turkey. Journal of Economics, Finance and Accounting (JEFA), V.5(2), p.168-183.

Permemant link to this document: http://doi.org/10.17261/Pressacademia.2018.823

Copyright: Published by PressAcademia and limited licenced re-use rights only.

\section{ABSTRACT}

Purpose - This study investigates announcement effect anomaly on Seasoned Equity Offerings (seos) conducted in Borsa Istanbul for the $2010-2015$ period and analyze its determinants.

Methodology - Event study and regression analysis were used to determine in order to observe abnormal returns in case of announcement performed. For the purpose of comparing results based on announcement was published or not, Paired Sample Statistics test was used. To find out announcement effect anomaly's determinants regression analysis was used through Panel Dynamic OLS (PDOLS) method.

Findings- Abnormal average returns and abnormal cumulative returns were observed as negative both in case of announcement or not. But negative returns is significantly higher when announcement is made.

Conclusion- Announcement effect anomaly has been confirmed and it has been determined that Leverage Change Ratio, Nominal Capital Increase, CAR $(-10,1)$ variables have positive effect on seos while $M / B$ ratio has negative effect.

Keywords: Announcement effect, seasoned equity offering, capital increase, abnormal stock returns, price anomalies.

JEL Codes: C23, G10, G32

\section{INTRODUCTION}

Some of the studies on seasoned equity offerings in the literature are related to announcement effect anomaly. It is possible to describe the effect of the announcement as the change in the stock prices following the public announcement of the company's stock issuances which conducted after initial public offering. Myers and Majluf (1984), Eckbo and Masulis (2005); describe the announcement effect as negative reaction to the stocks which overvalued.

Asquith and Mullins (1986), have separated seasoned equity issuances as primary and secondary issuances. They define the primary issuance as a new share issuance that increases the shares in the free float of the company while they describe the secondary seasoned equity issuance as the issuance of the shares held by the existing shareholders. In other words that has not increased the number of company shares.

In most of the studies performed in the previous literature, negative announcement effect was observed in seasoned equity offerings. The negative effect of the announcement shows that when the investors realise announcement, they apply downward revision in valuing of the stocks. Although the majority of the studies carried out indicate a negative effect, but in some studies the positive effect of the announcement has also been confirmed.

The study of Asquith \& Mullins (1986) and Masulis \& Korwar (1986), which can be regarded as the first of the studies related to the announcement effect show that on average $3 \%$ of the negative announcement effect was calculated on the announcement day compared to two days before last day.

However, Eckbo and Masulis (1995) pointed out that in the capital increases in which the subscription rights used (public placements) and Wruck (1989) argued in capital increases which allocated to only a specific investors (private placements), 
negative announcement effects have not been identified. In fact, according to the results of studies conducted in some other countries outside the US, the announcement effect is also calculated positively.

Eckbo, Masulis and Norli (2005), defined announcement effect which is generally considered negative in the initial and seasoned equity offerings, as the indirect issuance costs of the company.

However, in seasoned offerings, the market reaction is generally negative, but the market response may be different in cases where the seasoned equity offering is completed and canceled. Mikkelson and Partch (1986), determined that in the case of the completion of seasoned offering, stock returns are positive in period between the announcement and the completion of the issuance but then it turns to negative. If the announcement is canceled, it is determined that the returns are negative in the period between announcement and issuance then turns to positive.

In this study; based on analyses made through the sample consisting of companies that performed seasoned equity offering for the 2010-2015 period in Borsa Istanbul, we tested announcement effect hypothesis is valid. For the purpose of confirming hypothesis we tried to find out whether announcement of seasoned offering creates a meaningful effect on the average abnormal return of the stocks.

\section{LITERATURE REVIEW}

Modigliani and Miller (1958), found that issuance of new stocks, which lead to a decrease in the leverage level of the company and hence in the per share earnings, convey a negative signal to the market and thus investors respond negatively to the announcement of new share issuance.

Scholes (1972), introduced two hypotheses regarding the announcement effect during seasoned seasoned equity offerings: price pressure hypothesis and transaction cost hypothesis. The price pressure hypothesis emphasizes that the issue of new stocks leads to a steady decline in stock prices, depending on the increase in the amount of stock circulating in the market. The transaction costs hypothesis suggests that investors have a negative response to the seasoned equity offerings as investors have to re-adjust their investment portfoilos so that they can buy them from issuance, which in turn increases the transaction costs of investors.

Myers and Majluf (1984), stated that when there is information asymmetry between firm management and investors in favor of firm management, firms first apply to internal financing sources and then they prefer external financing sources. They also underlined that in terms of using external sources they first prefer debt financing and then they tend to issue stocks. In the literature, this is called the pecking order theory.

Before the seasoned equity offering, if there is information that may effect value of stocks of companies but the investors haven't aware of yet, it is called asymetric information and according to Myers and Majluf (1984) it is inevitable because of two reasons:

- Information are shared with the investors through the announcements that include important decisions may affect the price of the stocks, carries the confidential information of the company to its competitors. Therefore company management may delay the disclosure of such kind of information.

- If the company is publicly held, the company will have many partners at different levels of knowledge and education and the company may not be able to explain each decision of management to the all investors particularly not having techinical background at all times. Therefore, it is accepted that the shareholder and senior management may not prefer to publish material disclosures prior to decisions to be taken.

Based on the reasons above, the asymmetric knowledge also gives the opportunity of market timing to the firm management. When the firm's stock becomes overvalued, the firm management tries to maximize the issuance revenue by choosing the seasoned equity offering as financing preference. As a result, the seasoned equity issuance decision of the company gives a negative signal to the investors and leads them to give negative response to the company's issuance. In the literature, this is called Existing Asset Value Signalling Hypothesis regarding the value of assets.

Miller and Rock (1985), argued that firms' issuance of new stocks give a negative signal to the market. In this hypothesis called the cash flow signalling, it is accepted that the stock issuance decision is perceieved by market as firms can not generate enough cash to finance its operations and investments because their liquidty ability are too low.

Mikkelson and Partch (1986), conducted study in seasoned offerings on stocks and debt instruments performed by 360 industrial firms in the US during the 1972-1982 period and found negative announcement effect in issuance. They asserted that change in stock prices are not related to the amount of new financing, the size of the IPO and the quality of the rating of the borrowing instrument etc. According to their analysis the financial instrument is the only significant determinant of the price reaction. In addition to this, they found that abnormal price movements after the announcements of completed 
issuance followed a reversal price movements when compared to the announcements after canceled and / or incomplete issuances.

Asquith and Mullins (1986), examined 531 public offerings of common shares performed by public and industrial firms in the US were made in the form of capital increases through underwriting during $1963-1981$ period. They calculated announcement effect for whole sample as - \%2,7 during the announcement period that they considered to be 2 days. Based on issuance method they found negative effect as - \%3 in primary issues, - \%2 in secondary issues and - \%3,2 in combined issues which include both primary and secondary issues. The results obtained confirm the negative announcement effect and consistent with the previous literature. They emphasized that primary offerings caused dilution in stocks due to increasing number of shares.

Jensen (1986), in his study called wasteful investment hypothesis, argued that financing through borrowing will have a controlling effect on the activities of the firm's managers and thus it increase the operational efficiency of the firm. He emphasized that thanks to use of debt, firms may have fewer initiatives on their cash flows and they must be more rational in all their decisions. Thus some typical agency problems such as moral hazard by Holmostrom in 1979 and adverse selection by Rock in 1986 may not be seen or may be reduced.

Barclay and Litzenberger (1988), observed an average - 1.3\% negative market response in the first 15 minutes following the announcement of public offering. However, in the hour following announcement of public offering, a negative response was observed slightly lower than returns of the first 15 minutes, at a statistically significant level. It has been determined that, issue size, the use of the fund obtained from the offering and the expected profitability of new investments don't correlate with announcement effect seen in the new share issue. Unlike many studies in the previous literature, it has been reported that after the completion of the new share issue, an average improvement as $1.5 \%$ in firm stock prices has been observed.

Eckbo and Masulis (1995), have examined the effect of the investment banking activities and the use of subscription right on the public offering. If investment bank believes that price determined during the pricing phase is overvalued, may ask the issuer to reduce the price of the issue and / or to withdraw it. This behaviour of investment banking may reduce the cost of asymmetric information. Participation of existing shareholders who are regarded much closer to company and have superior and confidential information, will be perceived as positive signal thanks to reducing adverse selection problem.

Bayless and Chaplinsky (1996), found that price reactions of the market for announcements of seasoned equity offerings in hot public offering markets was an average of 200 base points lower than the response to the seasoned equity offerings made during cold public offerings markets. Findings obtained based analysis confirm that firms are going to apply the opportunity window in stock issuance.

Eckbo, Masulis and Norli (2005), during 1980-2004 period, observed that only half of the publicly traded companies in the US issued any financial instruments after the initial public offering, and a quarter of them made seasoned equity offerings. They emphasized that this is related to the cost of adverse selection should be taken into consideration when companies want to provide their financing needs from extrernal reseources.

They found the announcement effect of stocks offered in the US through full underwriting is negative. In their study, it was reported that the negative announcement effect seen in the private sector includes industrial firms is more severe than public firms. They calculated two-day abnormal return as - \% 3 in industrial companies while they found as - \% 1 in public firms. They stated that the lower market response seen in public firms was consistent with adverse selection model. Because when public firms are compared to private sector companies, they have less initiative to make timing for overvaluation of stocks in short term.

Wu, Wang and Yao (2005), studied on a sample included 405 seasoned equity offerings based on private and public placement made by industrial firms under the full underwriting during the period of $1989-1997$ in the Hong Kong stock Exchange. According to the results of the analysis, positive announcement effect was determined in seasoned equity offerings which made both in the form of public offerings and private offerings. They calculated abnormal returns as $\% 2$ in private offerings while they realised $\% 1,9$ return in public placement during the announcement period included 2 days. Via the regression analysis they applied, it has been determined that there is an significiant statistical relationship between the returns on the announcement day and the concentration level of the company's capital both in private and public placements. It is also emphasized that in the analysis, relationship between the announcement day returns and the huge amount of new share issuance will be positive if the concentration in the capital is over $40 \%$. It is argued that firms with relatively low market value / book value ratios, but whose growth rate is uncertain, are more likely to be seen the positive announcement effect in their stocks. They also found that the firm size had a significant effect in the announcement effect anomaly that seen in the seasoned equity offering. They observed higher announcement effect in new stock issuances made by relatively small issuers. They attribute this to asymmetric information in small-scale issuer firms is more related investment opportunities than the existing assets available. 
Shen (2006), analyzed the capital increases were performed in the Shenzhen and Shanghai stock exchanges during the 1993-2003 period, including 72 public offerings and 567 capital increases that subscription rights were used. According to the results of the analysis, similar to the developed countries' stock markets, the decrease in stock prices observed on the announcement day, that is, the negative announcement effect was confirmed. It has been found that the impact of the announcement is positively correlated with the proportion of Chinese publicly companies whose shares owned by the gorverment. Also the poor performance in the public offerings is greater in the capital increases in which the subscription right is used. According to market and risk adjusted returns, the two-day average abnormal returns are calculated as $\% 1,1$ for public offerings and calculated as $0.43 \%$ for capital increases that subscription right is used. It has been noted that these negative abnormalities detected in China differ from previous studies conducted in Japan, Singapore and Korea, but are compatible with studies performed in the United States, England and France.

Shahid et al. (2010), examined price reactions for the announcement of different types of share issuances of 717 seasoned equity offerings conducted during period of 1998- 2008, in which 565 capital increases that susbcription rights were used and 152 were performed in the form of direct public sale. In the analysis, unlike the previous literature, three different announcement dates were taken into account include the date of the board meeting, the date of the general assembly meeting and the date when the public announcement was made. Findings according to the analysis results show that the market has a positive response to the capital increases in which the subscription right is used, but seasoned equity offerings have a negative signal to investors. While the negative announcement effect was observed in the seasoned equity offerings on the all dates of announcements, the dates on which the market responded most were the date of the board of directors, the announcement date of the public announcement and the date of the general meeting respectively.

Ruutu (2010), found that the returns of announcement period in seasoned equity offerings fluctuates somewhat depending on the type of issue. In the study, as issue type accelerated offerings and book building at a fixed price were used. Accelerated offerings method was examined under two subheadings covers bought deal and accelerated book building. According to the underwriting methods examined in the sample, the most positive return was seen in the type of full underwriting.

Ahsan and Alam (2014), analysed the impact of the announcement effect in the sample consist of 83 seasoned equity offerings include subscription right usage and capital increase during the period of $2006-2012$ in Bangladesh. The results of the analysis were consistent with the literature and found the existence of abnormal returns on the day of the announcement and nearest days. Regarding the daily sectoral distribution of abnormal returns, it is found that the most abnormal returns are seen in the textile sector and the lowest abnormal returns are seen in the banking sector.

\section{DATA AND METHODOLOGY}

\subsection{Sample Construction}

In this study, the data of firms that performed seasoned equity offerings between 2010 and 2015 were analyzed. 79 seos performed by 58 publicly held companies during analyze period are included for the first form of sample construction. Like Asquith and Mullins (1986), Dubois and Jeanneret (2000) and Allen and Soucik (2008); in order to prevent overlap problems only first seos issues are included to sample during analyze period by ignoring subsequent seo issues were conducted by the same companies in the same period. Therefore 67 seos performed by 52 firms were included to the final sample. The data analyzed in the sample consist of the company's stock announcements dates and issuance dates, closing values (prices) of the stocks and BIST 100 index for the related period, returns calculated based on closing prices and the financials of the companies. Data of stocks and BIST 100 were obtained daily basis from Borsa Istanbul for the analysis period. Announcements of seasoned equity issuance of the companies were analyzed through the official site of Public Disclosure Platform (www.kap.gov.tr) by examining the material disclosures of each company for the related period. Since the company's seasoned equity offering was announced for the first time by the decision of the board of directors, the decision date of the company's board of directors was taken into consideration as the date of the announcement.

\subsection{Model}

During the analysis of this study, event study and regression method was used. In event studies main actions should be taken as follow (Kaya, 2012: 67, Mazgit, 2013: 236-237) :

- A regression estimate is made by assuming the existence of a linear relationship between firm return (ri) and market return $(\mathrm{rm})$ in the estimation window. In such studies, a specific period before the announcement is called the regression period or the estimation window (Brown and Warner, 1985). Regression period is used to determine the normal behavior of the asset returns compared market returns when there is no any event (in this study seasoned equity announcement). Pre-event observation should include 252 days or at least 126 days in the forecast window so that actual price movements can be defined (Beninga, 2012: 373). In this study, because the period of obtaining permission from Capital Markets Boards (CMB), which is the regulator of capital markets in Turkey, lasts about 1-1.5 
months before the announcement of the decision to increase capital, the regression period which designed prediction window by starting 46 days before the announcement date as Dutordoir and Hodrick's study in 2012 was used. Based on regression analysis performed in this study, we want to clarify that if the companies do not make seasoned equity offerings, what the expected returns of the stocks would be. Then, using the parameters of the calculated regression, in parallel with the study of Asquith and Mullins in 1986, the announcement observation period was considered to be the 10-day period covers before and after the seasoned equity offering $(-10,+10)$, and the expected returns, abnormal returns and cumulative abnormal returns are calculated for this period. These results obtained; represent the expected abnormal returns of the stock under the assumption that there is no seasoned equity offering has occurred. Figure 1 below shows below the regression and observation period used in the model.

Figure 1: Regression and Observation Period Used in Model

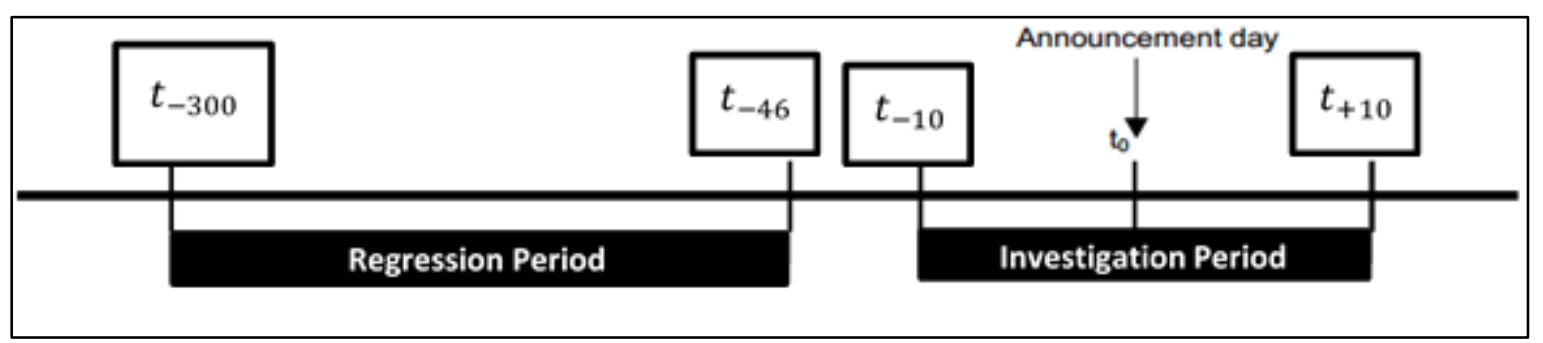

- In the next stage, the abnormal returns are calculated by using the stocks returns and market returns in the seasoned equity offering for the investigation period (ie. using the actual observation values), then the average and cumulative average abnormal returns are reached by using these values. Finally, the findings obtained by these two analyzes are compared and tried to find out whether the announcement effect exists or not. It is decided that the hypothesis of announcement effect is valid when there is a meaningful difference between the two analysis findings while it can be rejected if there is no meaningful difference.

First of all, in order to initiate calculations for each firm, daily returns of stocks (ri) and market (rm) values for the related period are calculated. Equations used in this process as follows;

$R_{i t}=\left(\frac{P_{i t}-P_{i t-1}}{P_{i t-1}}\right) * 100$

$R_{m t}=\left(\frac{P_{m t}-P_{m t-1}}{P_{m t-1}}\right) * 100$

Here $P_{i t}$ is the stock price of firm $i$ at time $t$ and $P_{m t}$ is the closing price at day $t$ of BIST100 index. In the next step, by using the values of these two series for $(-300,-46)$ period and equation $(3)$, for each firm (for the 67 seasoned equity offerings in which the data set is appropriate in this study), $\alpha$ and $\beta$ coefficients were estimated by making separate equation estimations using ordinary least squares method.

$R_{i t}=\alpha_{i}+\beta_{i} R_{m t}$

The parameters obtained are shown in Table 1. This was performed with Eviews 9.0 program

Table 1: Coefficients Calculated in the Prediction Window

\begin{tabular}{ccc}
\hline $\boldsymbol{I d}$ & $\boldsymbol{A l f a}(\boldsymbol{\alpha})$ & Beta $(\boldsymbol{\beta})$ \\
\hline 1 & 0.003 & 0.351 \\
\hline 2 & 0.044 & 0.795 \\
\hline 3 & 0.126 & 0.727 \\
\hline 4 & -0.241 & 0.836 \\
\hline 5 & -0.130 & 0.783 \\
\hline 6 & 0.196 & 0.709 \\
\hline
\end{tabular}




\begin{tabular}{|c|c|c|}
\hline 7 & 0.071 & 0.385 \\
\hline 8 & 0.130 & 0.635 \\
\hline 9 & 0.964 & 0.388 \\
\hline 10 & -0.085 & 0.405 \\
\hline 11 & 0.054 & 0.946 \\
\hline 12 & -0.199 & 0.732 \\
\hline 13 & -0.246 & 0.119 \\
\hline 14 & -0.204 & 0.374 \\
\hline 15 & 0.077 & 0.589 \\
\hline 16 & 0.011 & 0.692 \\
\hline 17 & 0.411 & 0.491 \\
\hline 18 & -0.032 & 0.921 \\
\hline 19 & -0.064 & 0.315 \\
\hline 20 & -0.079 & 0.541 \\
\hline 21 & 1.072 & 1.020 \\
\hline 22 & -0.033 & 0.431 \\
\hline 23 & -0.046 & 0.782 \\
\hline 24 & 0.347 & 0.243 \\
\hline 25 & -0.004 & 0.777 \\
\hline 26 & -0.038 & 0.840 \\
\hline 27 & 0.228 & 1.150 \\
\hline 28 & 0.429 & 0.402 \\
\hline 29 & -0.048 & 0.567 \\
\hline 30 & -0.085 & 0.942 \\
\hline 31 & 0.067 & 0.610 \\
\hline 32 & -0.078 & 0.734 \\
\hline 33 & -0.253 & 0.851 \\
\hline 34 & 0.081 & -0.015 \\
\hline 35 & 0.008 & 0.090 \\
\hline 36 & -0.027 & 0.823 \\
\hline 37 & 0.205 & 0.468 \\
\hline 38 & -0.137 & 0.430 \\
\hline 39 & 0.197 & 0.964 \\
\hline 40 & 0.324 & 0.696 \\
\hline 41 & 0.117 & 0.972 \\
\hline 42 & -0.053 & 0.528 \\
\hline 43 & 0.056 & 0.676 \\
\hline 44 & 0.153 & 0.642 \\
\hline 45 & 0.906 & 0.249 \\
\hline 46 & 0.124 & 0.423 \\
\hline 47 & -0.264 & 0.768 \\
\hline
\end{tabular}




\begin{tabular}{|c|c|c|}
\hline 48 & 0.129 & 0.908 \\
\hline 49 & -0.122 & 0.495 \\
\hline 50 & 0.033 & 0.652 \\
\hline 51 & -0.688 & 0.729 \\
\hline 52 & -0.048 & 0.375 \\
\hline 53 & 0.109 & 0.410 \\
\hline 54 & -0.114 & 0.861 \\
\hline 55 & 0.892 & 0.766 \\
\hline 56 & -0.058 & 0.802 \\
\hline 57 & -0.091 & 0.397 \\
\hline 58 & -0.076 & 0.726 \\
\hline 59 & -0.017 & 0.531 \\
\hline 60 & -0.185 & 0.413 \\
\hline 61 & 0.191 & 0.635 \\
\hline 62 & 0.341 & 0.164 \\
\hline 63 & 0.021 & 0.700 \\
\hline 64 & 0.005 & 0.829 \\
\hline 65 & 0.031 & 0.551 \\
\hline 66 & -0.161 & 0.828 \\
\hline 67 & 0.254 & 0.994 \\
\hline
\end{tabular}

By using $\alpha$ and $\beta$ coefficients obtained, for each company expected returns were calculated seperately for investigation period $(-10,+10)$. The equation used in this process is;

$E\left(R_{i t}\right)=\alpha_{i}+\beta_{i} R_{m t}$

$E$ (Rit) refers to expected returns of company $i$ and Rmt refers to the return of the BIST100 index for the day $t$. Using the equation (5), the abnormal return $\left(A R_{i t}\right)$ of each firm is calculated.

The equation used in this process (Asquith and Mullins, 1986: 68);

$A R_{i t}=R_{i t}-E\left(R_{i t}\right)$

Then, using these AR values, a cumulative abnormal return (CAR) for each firm is calculated. The equation used in this process (Asquith and Mullins, 1986: 68);

$C A R_{t_{1}}^{t_{2}}=\sum_{t=t_{1}}^{t_{2}} A R_{t}$

Using the previously calculated AR values, the Average Abnormal Returns (AAR) for each date were calculated. The equation used in this process (Asquith and Mullins, 1986: 68);

$A A R_{t}=\frac{1}{N} \sum_{i=1}^{N} A R_{i t}$

Using CAR_t values in a similar manner, Cumulative Average Abnormal Returns (CAAR) for each date were calculated. The equation used in this process (Asquith and Mullins, 1986: 69);

$C A A R_{t_{1} t}^{t_{2}}=\frac{1}{N} \sum_{i=1}^{N} C A R_{t_{1 i}}^{t_{2}}$ 
Calculated AAR and CAAR values are divided by their standard deviation to reach $t$ statistics. The formula used to calculate standard deviation is:

$\sigma=\sqrt{\frac{1}{(n-2)}\left[\sum(y-\bar{y})^{2}-\frac{\left[\sum(x-\bar{x})(y-\bar{y})\right]^{2}}{\sum(x-\bar{x})^{2}}\right]}$

The formulas used to calculate the t statistic are:

$t=\frac{A R_{t}}{\sigma}$

$t=\frac{C A R_{t}}{\sigma}$

\section{FINDINGS AND DISCUSSIONS}

\subsection{Test Results about Hypotheses on Seos Existence Seos}

The AAR and CAAR values obtained as a result of these operations are shown in Table 2. This was done using the SPSS 22 program and MS Office Excel 2013.

Table 2: AAR and CAAR Values Without Announcement

\begin{tabular}{|c|c|c|c|c|}
\hline$D A Y$ & $A A R$ & $t$ ist & $C A A R$ & $t$ ist \\
\hline-10 & 0.146 & 0.501 & -0.127 & -0.315 \\
\hline-9 & 0.009 & 0.021 & 0.158 & 0.303 \\
\hline-8 & 0.122 & 0.352 & 0.280 & 0.448 \\
\hline-7 & -0.075 & -0.200 & 0.205 & 0.286 \\
\hline-6 & 0.176 & 0.512 & 0.382 & 0.439 \\
\hline-5 & 0.460 & 1.138 & 0.842 & 0.906 \\
\hline-4 & 0.205 & 0.606 & 1.047 & 1.063 \\
\hline-3 & 0.353 & 0.788 & 1.401 & 1.255 \\
\hline-2 & 0.691 & 1.439 & $2.092^{*}$ & 1.726 \\
\hline-1 & -0.232 & -0.686 & 1.860 & 1.561 \\
\hline 0 & -0.618 & -0.982 & 1.241 & 0.874 \\
\hline 1 & $-2.104 * *$ & -2.471 & -0.940 & -0.537 \\
\hline 2 & -0.02 & -0.037 & -0.882 & -0.445 \\
\hline 3 & $-1.459 * * *$ & -3.226 & -2.342 & -1.243 \\
\hline 4 & -0.487 & -1.316 & -2.829 & -1.430 \\
\hline 5 & 0.705 & 1.399 & -2.124 & -0.980 \\
\hline 6 & 0.273 & 0.770 & -1.850 & -0.812 \\
\hline 7 & $-0.498 *$ & -1.843 & -2.349 & -1.022 \\
\hline 8 & -0.213 & -0.834 & -2.562 & -1.089 \\
\hline 9 & $-0.765 * *$ & -2.368 & -3.327 & -1.444 \\
\hline 10 & -0.185 & -0.415 & -3.411 & -1.527 \\
\hline
\end{tabular}

Note: $* * * * *$, and $*$; refer to the relevant value is statistically significant at $1 \%, 5 \%$ and $10 \%$ significance levels, respectively.

According to the results in table 2; negative average abnormal return on stocks occurred on days $1,3,7$ and 9 following announcement of seasoned equity offering. In CAAR values, average abnormal return of the stocks was negative for the period of two days prior to the announcement of the seasoned equity offerings. 
In the analyzes made so far, it has been worked under the assumption that no seasoned equity offerings announcement has been made. In order to calculate $A A R^{a}$ ve $C A A R^{a}$ values for the case which seasoned equity offerings were performed actual $P_{i t}$ ve $P_{m t}$ values for the investigation period and $R_{i t}$ and $R_{m t}$ values calculated based on equation (1) and equation (2) were used. The formula used to calculate the abnormal return in the case of the seasoned equity offering (Asquith and Mullins, 1986: 68):

$$
A R_{i t}^{a}=R_{i t}-R_{m t}
$$

$A R_{i t}^{a} ;$ indicates abnormal returns in the case of an announcement.

Using $A R^{a}$ values and equation (13) the cumulative abnormal returns $\left(C A R^{a}\right)$ were calculated as follows:

$C A R_{t_{1} t}^{t_{2} a}=\sum_{t=t_{1}}^{t_{2}} A R_{t}^{a}$

In the next stage, based on $A R^{a}$ and $C A R^{a}$ values and equation (14) and equation (15) average abnormal returns $\left(A A R^{a}\right)$ and average cumulative abnormal returns $\left(C A A R^{a}\right)$ were calculated.

$A A R_{t}^{a}=\frac{1}{N} \sum_{i=1}^{N} A R_{i t}^{a}$
$C A A R_{t_{1}}^{t_{2} a}=\frac{1}{N} \sum_{i=1}^{N} C A R_{t_{1 i}}^{t_{2}}$

Finally, standard deviation were calculated using Equation (9) and t statistics are obtained using Equation (10). The findings are listed in Table 3:

Table 3 : AAR $^{\mathrm{a}}$ and CAAR $^{\mathrm{a}}$ Values After Announcement

\begin{tabular}{|c|c|c|c|c|}
\hline DAY & $\mathrm{AAR}^{\mathrm{a}}$ & $t$ ist. & CAAR $^{a}$ & $t$ ist. \\
\hline-10 & 0.005 & 0.012 & -0.042 & -0.103 \\
\hline-9 & -0.201 & -0.379 & -0.244 & -0.309 \\
\hline-8 & -0.217 & -0.487 & -0.461 & -0.426 \\
\hline-7 & -0.472 & -1.011 & -0.934 & -0.686 \\
\hline-6 & -0.029 & -0.067 & -0.963 & -0.578 \\
\hline-5 & 0.228 & 0.461 & -0.734 & -0.372 \\
\hline-4 & -0.168 & -0.386 & -0.903 & -0.402 \\
\hline-3 & 0.060 & 0.114 & -0.842 & -0.330 \\
\hline-2 & 0.457 & 0.809 & -0.385 & -0.135 \\
\hline-1 & -0.386 & -0.893 & -0.771 & -0.249 \\
\hline 0 & -0.647 & -0.930 & -1.419 & -0.411 \\
\hline 1 & $-2.133 * *$ & -2.439 & -3.552 & -0.934 \\
\hline 2 & -0.117 & -0.196 & -3.670 & -0.877 \\
\hline 3 & $-1.142 * *$ & -1.982 & -4.812 & -1.258 \\
\hline 4 & -0.110 & -0.236 & -4.922 & -1.347 \\
\hline 5 & 0.516 & 0.997 & -4.406 & -1.140 \\
\hline 6 & 0.320 & 0.913 & -4.085 & -1.036 \\
\hline 7 & $-0.648 * *$ & -2.068 & -4.733 & -1.162 \\
\hline 8 & -0.433 & -1.525 & -5.167 & -1.231 \\
\hline 9 & $-0.936 * * *$ & -2.616 & -6.103 & -1.418 \\
\hline 10 & 0.152 & 0.342 & -5.809 & -1.392 \\
\hline
\end{tabular}


Note: ${ }^{* * *}$ and ${ }^{* *}$; refers that related values are statistically significant at $1 \%$ and $5 \%$ significance level respectively.

According to the results shown in Table 3; negative average abnormal returns of stocks on the 1st, 3rd, 7th and 9th days following announcement related seasoned equity offerings was observed. In other words, negative effect seen in related days when the companies announce their capital increase decision. However, it was found that cumulative average abnormal returns before and after the public announcement of the seasoned equity offering were not statistically significant.

Based on average abnormal returns, hypotheses used to find out whether announcement effect exist:

$\mathrm{H}_{1,0}: \mathrm{AAR}_{\mathrm{t}}=\mathrm{AAR}_{\mathrm{t}}^{\mathrm{a}} \quad$ Average abnormal returns are not significantly different from each other. That is, the announcement effect hypothesis can be rejected.

$\mathrm{H}_{1,1}: \mathrm{AAR}_{\mathrm{t}} \neq \mathrm{AAR}_{\mathrm{t}}^{\mathrm{a}} \quad$ Average abnormal returns are significantly different from each other. That is, the announcement effect hypothesis can not be rejected.

Based on on cumulative average abnormal returns, hypotheses used to find out whether announcement effect exist:

$\mathrm{H}_{2,0}: \mathrm{CAAR}_{\mathrm{t}}=\mathrm{CAAR}_{\mathrm{t}}^{\mathrm{a}}$ Cumulative average abnormal returns are not significantly different from each other. That is, the announcement effect hypothesis can be rejected.

$\mathrm{H}_{2,1}: \mathrm{CAAR}_{\mathrm{t}} \neq \mathrm{CAAR}_{\mathrm{t}}^{\mathrm{a}}$ Cumulative average abnormal returns are significantly different from each other. That is, the announcement effect hypothesis can not be rejected.

If the HO hypotheses can not be rejected, the announcement effect hypothesis will be accepted as valid for the related days.

In order to test these hypotheses, table 4. was prepared by evaluating results based on Table 2 . and Table 3. together.

Table 4: AAR and CAAR Values Without Announcement and $A A R^{a}$ and CAAR $^{\mathrm{a}}$ Values After Announcement

\begin{tabular}{|c|c|c|c|c|}
\hline DAYS & AAR & CAAR & AAR $^{a}$ & CAAR $^{a}$ \\
\hline-10 & 0.146 & -0.127 & 0.005 & -0.042 \\
\hline-9 & 0.009 & 0.158 & -0.201 & -0.244 \\
\hline-8 & 0.122 & 0.280 & -0.217 & -0.461 \\
\hline-7 & -0.075 & 0.205 & -0.472 & -0.934 \\
\hline-6 & 0.176 & 0.382 & -0.029 & -0.963 \\
\hline-5 & 0.460 & 0.842 & 0.228 & -0.734 \\
\hline-4 & 0.205 & 1.047 & -0.165 & -0.903 \\
\hline-3 & 0.353 & 1.401 & 0.060 & -0.842 \\
\hline-2 & 0.691 & $2.092 *$ & 0.457 & -0.385 \\
\hline-1 & -0.232 & 1.860 & -0.386 & -0.771 \\
\hline 0 & -0.618 & 1.241 & -0.647 & -1.419 \\
\hline 1 & $-2.104 * *$ & -0.940 & $-2.133 * *$ & -3.552 \\
\hline 2 & -0.02 & -0.882 & -0.117 & -3.670 \\
\hline 3 & $-1.459 * * *$ & -2.342 & $-1.142 * *$ & -4.812 \\
\hline 4 & -0.487 & -2.829 & -0.110 & -4.922 \\
\hline 5 & 0.705 & -2.124 & 0.516 & -4.406 \\
\hline 6 & 0.273 & -1.850 & 0.320 & -4.085 \\
\hline 7 & $-0.498^{*}$ & -2.349 & $-0.648 * *$ & -4.733 \\
\hline 8 & -0.213 & -2.562 & -0.433 & -5.167 \\
\hline 9 & $-0.765 * *$ & -3.327 & $-0.936 * * *$ & -6.103 \\
\hline 10 & -0.185 & -3.411 & 0.152 & -5.809 \\
\hline
\end{tabular}

When the results in Table 1.4 are considered; the $H_{2,0}$ hypothesis was rejected at the level of significance of $10 \%$ and it was decided that the announcement effect hypothesis was valid for only on the second day before the announcement of the seasoned equity offering because the CAAR value was statistically significant only this day. On the 1st, 3rd, 7th and 9th days after announcement of the seasoned equity offering, there is a negative and statistically significant average abnormal returns regardless seasoned quity offering announcement published. During the investigation period, the returns calculated on the assumption that the seasoned equity offering announcement was not made were negative. After the announcement of the seasoned equity offering published the negative return both on the announcement date and after continued. If there is a meaningful difference between the two returns, the announcement effect hypothesis will be accepted for the stocks of 
companies that make seasoned equity offerings during the analysis period. In other words, the existence of more negative and / or less negative returns will be questioned if the company publish announcement offering.

Paired sample statistics $t$ test was used to determine whether there is a significant difference between AAR - AARa values and CAAR - CAARa values. This test is effective in testing whether the average of measurements of a group's separate criteria differ (Akdağ, 2011). In this context, table 5. shows test results rest on AAR and AARa values.

Table 5: Paired Samples Test - AAR\& AARa

\begin{tabular}{|c|c|c|c|c|c|c|c|c|}
\hline & \multicolumn{5}{|c|}{ Paired Differences } & \multirow{3}{*}{$t$} & \multirow{3}{*}{ df } & \multirow{3}{*}{ Sig. (2-tailed) } \\
\hline & \multirow[t]{2}{*}{ Mean } & \multirow{2}{*}{$\begin{array}{c}\text { Std. } \\
\text { Deviation }\end{array}$} & \multirow{2}{*}{$\begin{array}{l}\text { Std. Error } \\
\text { Mean }\end{array}$} & \multicolumn{2}{|c|}{$\begin{array}{l}\text { 95\% Confidence Interval of the } \\
\text { Difference }\end{array}$} & & & \\
\hline & & & & Lower & Upper & & & \\
\hline $\begin{array}{l}\text { AAR - } \\
\text { AAR }^{a}\end{array}$ & 0.113 & 0.220 & 0.048 & 0.013 & 0.214 & 2.361 & 20 & 0.029 \\
\hline
\end{tabular}

Since the probability value (0.029) in Table 1.5 is smaller than $0.05, H_{1,0}$ hypothesis was rejected and it was decided that there was a significant difference between AAR and AARa values. Based on the AAR values, it can be assumed that the announcement effect hypothesis is valid. Table 6 . shows test results rest on CAAR and CAARa values.

Table 6: Paired Samples Test - CAAR\& CAARa

\begin{tabular}{|c|c|c|c|c|c|c|c|c|}
\hline & \multicolumn{5}{|c|}{ Paired Differences } & \multirow{3}{*}{$t$} & \multirow{3}{*}{ df } & \multirow{3}{*}{ Sig. (2-tailed) } \\
\hline & \multirow{2}{*}{ Mean } & \multirow{2}{*}{$\begin{array}{c}\text { Std. } \\
\text { Deviation }\end{array}$} & \multirow{2}{*}{$\begin{array}{l}\text { Std. Error } \\
\text { Mean }\end{array}$} & \multicolumn{2}{|c|}{$\begin{array}{l}\text { 95\% Confidence Interval } \\
\text { of the Difference }\end{array}$} & & & \\
\hline & & & & Lower & Upper & & & \\
\hline CAAR - CAAR ${ }^{a}$ & 1.987 & 0.824 & 0.179 & 1.612 & 2.362 & 11.049 & 20 & 0.000 \\
\hline
\end{tabular}

Since the probability value $(0.029)$ in Table 6 . is smaller than $0.05, H_{2,0}$ hypothesis was rejected and it was decided that there was a significant difference between CAAR and CAARa values. Similarly, by looking at the CAAR values, it can be assumed that the announcement hypothesis is valid.

When the results obtained from this analysis are generally evaluated; it can be claimed that the seasoned equity offerings announcement has a statistically significant effect on the average abnormal returns and the cumulative average abnormal returns of the stocks. From this point, it can be claimed that the announcement effect hypothesis is valid for the companies that offered to the public between 2010 and 2015. Announcement effect was observed as negative. Based on the findings shown in table 1.2, if the announcement was made during the investigation period, it is seen that the stock returns are lower than when the announcement done. If the announcement is not made, the cumulative abnormal return of stocks on the 10th day after the announcement date calculated as approximately - 3.4\%, while in case of existence of announcement the cumulative abnormal return on the 10th day following the announcement calculated as $5.8 \%$. Based on these calculated values, the existence of a negative announcement effect is confirmed for the sample consisting of companies that have made seasoned equity offerings in Borsa Istanbul during the analysis period.

\subsection{Determinants of Announcement Effect}

At the end of the analysis, the determinants of the announcement effect will be found by panel data analysis methods. For this purpose, AARa and CAARa used as dependent variables while leverage ratio change (LC), issue size (nominal value of shares sold: IS), CAR(-10,-1) (CAR) and Market Value / Book Value ratio (M/B) were used as in dependent and following models were created :

Model 1: $A A R_{t}^{a}=\beta_{0}+\beta_{1} L C_{i t}+e_{i t}$

Model 2: $A A R_{t}^{a}=\alpha_{0}+\alpha_{1} I S_{i t}+u_{i t}$ 
Model 3: $A A R_{t}^{a}=\delta_{0}+\delta_{1} C A R_{i t}+v_{i t}$

Model 4: $A A R_{t}^{a}=\theta_{0}+\theta_{1} M / B_{i t}+\varepsilon_{i t}$

Model 5: $\operatorname{CAAR}_{t}^{a}=\beta_{0}+\beta_{1} L C_{i t}+e_{i t}$

Model 6: $\operatorname{CAAR}_{t}^{a}=\alpha_{0}+\alpha_{1} I S_{i t}+u_{i t}$

Model 7: $C_{A A R_{t}^{a}}=\delta_{0}+\delta_{1} C A R_{i t}+v_{i t}$

Model 8: $C A A R_{t}^{a}=\theta_{0}+\theta_{1} M / B_{i t}+\varepsilon_{i t}$

Among these models, Model (1) and Model (5) for Leverage Effect Hypothesis, Model (2) and Model (6) for Price Pressure Hypothesis, Model (3) and Model (7) for Signalling Hypothesis and Model (4) and Model (8) for Growth Opportunities Effect Hypothesis used to test above mentioned hypotheses. Due to the size of the CAR $(-10,-1)$, the time dimension of all these analyzes was taken as $(-10,-1)$ period. In this case, the time dimension of the analysis $T$ was regarded as 10 and the horizontal section size $\mathrm{N}$ was taken as 67.

Descriptive statistics of the variables included in these models are presented in Table 7:

Table 7: Descriptive Statistics for Variables

\begin{tabular}{|c|c|c|c|c|c|}
\hline & $A A R^{a}$ & & $C A A R^{a}$ & & $L C$ \\
\hline Mean & -0.072 & Mean & -0.628 & Mean & -5.298 \\
\hline Median & -0.098 & Median & -0.753 & Median & -1 \\
\hline Maximum & 0.457 & Maximum & -0.042 & Maximum & 35 \\
\hline Minimum & -0.472 & Minimum & -0.963 & Minimum & -58 \\
\hline Std. Dev. & 0.265 & Std. Dev. & 0.306 & Std. Dev. & 14.561 \\
\hline Skewness & 0.417 & Skewness & 0.612 & Skewness & -1.198 \\
\hline Kurtosis & 2.502 & Kurtosis & 1.977 & Kurtosis & 5.645 \\
\hline Jarque-Bera & 26.406 & Jarque-Bera & 71.140 & Jarque-Bera & 355.764 \\
\hline Probability & 0.000 & Probability & 0.000 & Probability & 0.000 \\
\hline Sum & -48.494 & Sum & -421.020 & Sum & -3550 \\
\hline Sum Sq. Dev. & 47.042 & Sum Sq. Dev. & 62.723 & Sum Sq. Dev. & 141860.3 \\
\hline \multirow[t]{2}{*}{ Observations } & 670 & Observations & 670 & Observations & 670 \\
\hline & IS & & CAR & & $M / B$ \\
\hline Mean & 178.985 & Mean & 1.400 & Mean & 6.390 \\
\hline Median & 78 & Median & -0.278 & Median & 2.550 \\
\hline Maximum & 3233 & Maximum & 53.082 & Maximum & 110.697 \\
\hline Minimum & 5 & Minimum & -28.539 & Minimum & -86.847 \\
\hline Std. Dev. & 413.815 & Std. Dev. & 8.189 & Std. Dev. & 24.424 \\
\hline Skewness & 6.1663 & Skewness & 1.785 & Skewness & 1.720 \\
\hline Kurtosis & 44.734 & Kurtosis & 10.914 & Kurtosis & 13.881 \\
\hline Jarque-Bera & 52870.35 & Jarque-Bera & 2104.66 & Jarque-Bera & 3635.891 \\
\hline Probability & 0.000 & Probability & 0.000 & Probability & 0.000 \\
\hline Sum & 119920 & Sum & 938.454 & Sum & 4281.815 \\
\hline Sum Sq. Dev. & $1.15 \mathrm{E}+08$ & Sum Sq. Dev. & 44872.94 & Sum Sq. Dev. & 399105.4 \\
\hline Observations & 670 & Observations & 670 & Observations & 670 \\
\hline
\end{tabular}

Regression analysis was performed through Panel Dynamic OLS (PDOLS) and results are shown in Table 8. 
Table 8: Regression Analysis Results

\begin{tabular}{|c|c|c|c|c|c|c|c|c|}
\hline \multirow[t]{2}{*}{$\begin{array}{c}\text { Independent } \\
\text { Variables }\end{array}$} & $\begin{array}{l}\text { Model } \\
(1)\end{array}$ & $\begin{array}{c}\text { Model } \\
(2)\end{array}$ & $\begin{array}{c}\text { Model } \\
(3)\end{array}$ & $\begin{array}{l}\text { Model } \\
(4)\end{array}$ & $\begin{array}{c}\text { Model } \\
(5)\end{array}$ & Model (6) & $\begin{array}{c}\text { Model } \\
(7)\end{array}$ & $\begin{array}{c}\text { Model } \\
(8)\end{array}$ \\
\hline & \multicolumn{4}{|c|}{ Dependent Variable AAR $^{a}$} & \multicolumn{4}{|c|}{ Dependent Variable CAAR $^{\mathrm{a}}$} \\
\hline$L C$ & $\begin{array}{c}0.001 * * \\
* \\
{[2.57]}\end{array}$ & - & - & - & $\begin{array}{c}0.01 * * * \\
{[5.13]}\end{array}$ & - & - & - \\
\hline IS & - & $\begin{array}{c}-0.001 * * * \\
{[-4.59]}\end{array}$ & - & - & - & $\begin{array}{c}- \\
0.0005^{* * *} \\
{[-6.08]}\end{array}$ & - & - \\
\hline$C A R$ & - & - & $\begin{array}{c}- \\
0.0001 \\
{[-0.08]}\end{array}$ & - & - & - & $\begin{array}{c}- \\
0.01 * * \\
* \\
{[-2.77]}\end{array}$ & - \\
\hline$M / B$ & - & - & - & $\begin{array}{c}- \\
0.0007^{* *} \\
{[-1.89]}\end{array}$ & - & - & - & $\begin{array}{c}- \\
0.006^{* *} \\
* \\
{[-3.70]}\end{array}$ \\
\hline$R^{2}$ & 0.06 & 0.09 & 0.07 & 0.06 & 0.72 & 0.55 & 0.06 & 0.94 \\
\hline $\bar{R}^{2}$ & 0.06 & 0.09 & 0.07 & 0.06 & 0.72 & 0.55 & 0.06 & 0.94 \\
\hline
\end{tabular}

Note: ${ }^{* * *}$ and ${ }^{* *}$; refers that related values are statistically significant at $1 \%$ and $5 \%$ significance level respectively. The square brackets indicate the $t$ statistics, and the normal parentheses indicate the probability value.

According to the findings in table 1.8 the explanatory levels $\left(R^{2}\right)$ of models $1,2,3,4$ and 7 are slightly lower. However, according to Gujarati (2004: 258-260), this will not a matter. Autocorrelation and variance problems in PDOLS method are solved by Newey - West method. Therefore, the results obtained are generally trustworthy.

In Model 1 and Model 5, the 1\% decrease in LC reduced the abnormal returns and the cumulative abnormal returns of stocks adjusted to market returns by $0.1 \%$ and $1 \%$, respectively. These values are statistically significant at $1 \%$ significance level.

Therefore, the Leverage Effect Hypothesis is valid for this sample.

In Model 2 and Model 6, a 1\% increase in IS appears to reduce abnormal returns and cumulative abnormal returns of stocks by $0.1 \%$ and $0.05 \%$, respectively. These values are statistically significant at $1 \%$ significance level. Therefore, the Price Pressure Hypothesis is valid for this sample.

It is seen that the $1 \%$ increase in CAR $(-10,-1)$ in Model 3 and Model 5 reduced the abnormal returns and cumulative abnormal returns of the stocks adjusted to market returns by $0.01 \%$ and $1 \%$, respectively. While the first of these values was not statistically significant, the second was significant at $1 \%$ significance level. Therefore, the Cash Flow Signal Hypothesis is valid in this sample.

A 1\% increase in M / B in Model 4 and Model 6 seems to reduce the abnormal returns and cumulative abnormal returns of stocks by $0.07 \%$ and $0.6 \%$, respectively. These values were statistically significant at $5 \%$ and $1 \%$ significance level, respectively. The hypothesis of the impact of growth opportunities assumes that firms with high $\mathrm{M} / \mathrm{B}$ rates are able to evaluate investment projects that have a higher added value and allow company to grow. Therefore high $\mathrm{M} / \mathrm{B}$ ratio can be regarded as a positive signal to the market. According to this hypothesis, the increase in this area will also increase the return of stocks. Therefore, it can be assumed that the Hypothesis of the Impact of Growth Opportunities is not valid since stock returns are negative and statistically significant when $\mathrm{M}$ / B rate increase for the analyzed sample. 


\section{CONCLUSION}

In this study, the existence of negative announcement effect anomaly was determined and confirmed statistically during the seasoned equity offerings held in Borsa Istanbul during 2010 - 2015 period. The announcement effect was calculated to be approximately $2.6 \%$ over the closing date of the 1 st trading day following the announcement, covering the entire sample, and it is significant at the $5 \%$ significance level. The main reason for the negative announcement effect observed in related period that majority firms of sample performed seasoned equity offerings are made in the form of a capital increase. On the other hand, positive announcement effects were observed in the seasoned equity offerings in the form of allocated capital increase, as opposed to the general outcomes.

Four independent variables were used in the study as determinants of the announcement effect. These are respectively; Leverage Change Ratio (LC), Cumulative Abnormal Returns (CAR) (-10,-1), Issue Size (Nominal value of shares sold: IS) and Market Value / Book Value (M/B MB). Each variable was used to test whether the hypotheses related to the announcement effect are valid in Borsa Istanbul for the analysis period. LC, IS, CAR $(-10,-1)$ and MB variables were used to test Levarage Effect Hypothesis, Price Pressure Hypothesis, Siganlling Hypothesis and Growth Opportunity Effect Hypothesis respectively.

The leverage effect hypothesis assumes that the increase in firm leverage will increase earnings per share due to the debt tax benefit and therefore the negative investor response will be observed when firms announce seasoned equity offering which decrease firm's leverage level. In the study, the firm leverage ratio was calculated as Total Liabilities / Total Assets. The leverage ratio change was also calculated by comparing the leverage ratio obtained from the year-end balance sheet published before the announcement of the seasoned equity offering and the ratio obtained from the year-end balance sheet published after the announcement. The findings obtained in the study confirm the hypothesis. It has been determined that the $1 \%$ decrease in the leverage ratio for the sample reduces the cumulative stock returns by $1 \%$. From here it can be assumed that the Leverage Effect Hypothesis is valid for the period of analysis in Borsa Istanbul.

The Price Pressure Hypothesis assumes that the seasoned equity offering of the firm, in other words capital increase, will lead to a steady decline in the share price. Moreover, according to the same hypothesis, the higher the issue size is assumed to cause the greater the decrease in stock value. The nominal amount of capital increase was taken into consideration as the size of the issue in the study. The company's capital increase is realized by issuing new stocks representing increasing capital, which means that the number of stocks in circulation increases. Therefore, it is accepted that according to the typical supply-demand law in the economy the amount of stock increased will decrease the value of the company. In the analysis, it was determined that the $1 \%$ increase in the issue size reduced the cumulative stock returns by $0.05 \%$ and this result is statistically significant at the $1 \%$ significance level. It has been confirmed that the Price Pressure Hypothesis is also valid for seasoned equity offerings made during the period of analysis in Borsa Istanbul.

The Signal Hypothesis assumes that the seasoned equity offering of the firm is a signal sent to the market. In the literature there are vast majör studies which underline negative signal effect of seasoned equity offerings. The firm's offering decision may be interpreted by current and potential investors in the market as having failed to provide and generate required fund to finance growth and / or investment activities. As a result, according to the hypothesis, due to this negative perception of investors related to the financials of the firm, there is a negative reaction from the market for the announcement of the company's seasoned equity offering and the firm's stocks may show sharply decline. This is called Signal Hypothesis or Cash Flow Signal Hypothesis. In this study, the CAR $(-10,-1)$ variable was used to measure the signal effect. According to the analysis results, it was determined that the $1 \%$ increase in this variable decreased the cumulative returns by $1 \%$. Similar to previous hypotheses, this hypothesis also has been confirmed by findings from the study.

Growth opportunity effect hypothesis assumes that firms with higher market value, thanks to their solid market perception, will be able to have more chance to evaluate investments opportunities which is more profitable and can accelerate company's growth than small companies. The M / B variable was used to measure the effect of this hypothesis in the study. In the analysis, the effect of the change in $\mathrm{M} / \mathrm{B}$ ratio on stock return was examined. The $\mathrm{M} / \mathrm{B}$ ratio change is calculated by comparing the ratios based on financials published after announcement and before announcement. According to hypothesis, high M / B multiplier can be regarded as positive signal sent to market thanks to being overvalued of firm's stock by the optimsit investors who believe firm's future financial stability. Therefore, it is expected that having high ratio will have positive effects on firm's stock returns. According to the findings of the analysis in the study, $1 \%$ increase in the ratio will decrease the cumulative returns of stocks by $0,6 \%$. This finding is also significiant at the $1 \%$ significance level. As a result, Growth opportunity effect hypothesis can not be accepted for the sample during the analysis period.

In this study, the effect of the announcement of the seasoned equity offering on the stock price performance and the determinants that caused it were examined by analyzing the market reaction that occurred when the seasoned equity offering was announced to the public. In order to prevent the overlapping problem for the returns calculated during the regression period which formed by the past price movements of the stocks, firms that have made more than one seasoned equity offerings during the analysis period, were excluded from the sample. Thus final sample included 67 firms. 
Based on calculation made in the analysis, average abnormal returns and cumulative abnormal returns has been observed regardless announcement made. On the other hand, it has determined that more negative returns were calculated when annoncement was made and this evidence is statistically significiant.

Therefore according to results of analysis, in Borsa İsanbul, announcement effect has been confirmed on seasoned equity offerings made during 2010 - 2015 period. According to the calculations made in the analyzes, the effect of the announcement was determined as negative. It is possible to think that the negative effect of announcement is due to fact that the majortiy of offerings made during the review period in the form of capital increases. As evidence observed in this study in line with majority of previous studies, offerings were made in the form of capital increases (public placement) lead to both current and potential investors to think that firms applied offerings are not capable of creating required cash flows to finance its investments operations while offerings made in private placement forms convey to market a positive signal that some investors are interested in the firms. Thus, investors react positively to private placements while give a negative response to the public placements. The findings are consistent with previous studies both in national and international literature.

The factors that caused the announcement effect were also analyzed in the analysis. Independent variables considered as determinants of the announcement effect in the study; Levarage Change Ratio (LC), Issue Size (IS), Market Value / Book Value (M / B Multiplies - MB) and Cumulative Abnormal Returns $(-10,-1)$ (CAR).

In the analysis, each of these variables was used to test previously generated hypotheses to explain the effect of the announcement seen in seasoned equity offerings. LC, IS, CAR $(-10,-1)$ and MB variables were used to test Levarage Effect Hypothesis, Price Pressure Hypothesis, Siganlling Hypothesis and Growth Opportunity Effect Hypothesis respectively.

According to the findings obtained from the analysis;

- The decline in the leverage ratio with the seasoned equity offering has been found to have a negative effect on the stock return of the firm, in other words, the Leverage Effect Hypothesis has been confirmed.

- The higher the amount of nominal capital raised as a result of the seasoned equity offering, the lower the firm's stock return was observed, indicating that the Price Pressure Hypothesis is also valid for the sample studied.

- Another finding in the analysis is that decrease of stock returns was observed as the increase in the CAR variable. Based on this finding, it is confirmed that the Signalling Hypothesis is valid.

- Finally; the increase in the M / B ratio variable has been found to have a negative effect on stock returns that is Growth Opportunities Effect Hypothesis is not valid for the sample.

\section{REFERENCES}

Ahsan, M. and Alam, N. 2014. Sectoral Decomposition of the Announcement Effect of Rights Offerings: Evidence from Bangladesh. Investment Management and Financial Innovations. 11(4): 254 -267.

Akdağ, M. 2011. SPSS'de İstatistiksel Analizler.https://cms.inonu.edu.tr/uploads/old/5/1328/spss-testleri.doc. [Erişim Tarihi : 09.08.2017].

Allen, D.E. and Soucik, V. 2008. Long Run Underperformance of Seasoned Equity Offerings Fact or An Illusion. Journal Mathematics and Computers in Simulation. 78 (3):146 - 154.

Asquith, P. and Mullins, D. W. 1986. Equity Issues and Offering Dilution. Journal of Financial Economics. (15): 61 - 89.

Barclay, J. and Litzenberger, H.R. 1988. Announcement Effect of New Equity Issues and The Use of Intraday Price Data. Journal of Financial Economics. 12(1): 71-99.

Bayless, M. and Chaplinsky, S. 1996. Is There a Window of Opportunity For Seasoned Equity Issuance ?. The Journal of Finance. 51 (1): 253 278.

Beninga, S. 2012. Financial Modelling (Third Edition). London: The Mit Press.

Brown, S.,J. and Warner, J. B. 1985. Using Daily Stock Returns. Journal of Financial Economics. 14(1): 3-31.

Dubois, M. and P. Jeanneret, 2000. The long-run performance of seasoned equity offerings with rights: evidence from the Swiss market [online]. Available: http://ssrn.com/ abstract $=239873$

Dutordoir, M. and Hodrick, L.S. 2012. Stock Returns Around Corporate Security Offering Announcements. Columbia Business School Research Paper. 12(11):1-55.

Eckbo, B. E. and Masulis, R. W. 1995. Seasoned Equity Offerings: A Survey. Series of Handbooks In Operations Research and Management Science. [online]. Available: http://ssrn.com/abstract $=1299872$

Eckbo, B. E., Masulis, R. W. and Norli, Q. 2005. Security Offerings. Handbook of Corporate Finance: Empirical Corporate Finance. [online]. Available: http://ssrn.com/abstract $=863664$ 
Gujarati, D.N. 2004. Basic Econometrics (Fourth Edition). McGraw Hill.

Jensen, C. M. 1986. Agency Costs of Free Cash Flow, Corporate Finance and Takeovers. American Economic Review. 76(2): 323 - 329.

Kaya, T. 2012. The Short Term Performance of Initial Public Offerings in Istanbul Stock Exchange: 2010-2011 Application. Journal of Business, Economics and Finance. 1(1): 64-76.

Masulis, R. W. and Korwar, A. N. 1986. Seasoned Equity Offerings: An Empirical Investigation. Journal of Financial Economics. 15(1/2): 91 118.

Mazgit, i̇. 2013. Endeks Kapsamında Olmanın Hisse Senedi Getirilerine Etkisi: BIST Temettü 25 Endeksi Üzerine Bir Uygulama. Sosyoekonomi Dergisi. 20(20): 225-264

Mikkelson, H. and W. Partch, M. M. 1986. Valuation Effects of Security Offerings and The Issuance Process. The Journal of Financial Economics. 15(1-2): 31-60.

Miller, H. M. and Rock, K. 1985. Dividend Policy Under Asymmetric Information. The Journal of American Finance Association. 40(4): 1031 1051.

Modigliani, F. and Miller, H. M. 1958. The Cost of Capital, Corporation Finance and The Theory of Investment. American Economic Association. 48(3): $261-297$.

Myers, S. C. and Majluf, N. S. 1984. Corporate Financing And Investment Decisions When Firms Have Information The Investors Do Not Have. Working Paper. National Bureau of Economic Research.

Ruutu, K. 2010. Ownership Structure And Choice of Issue Method In Seasoned Equity Offerings. Master Thesis. Helsinki School of Economics Accounting and Finance Department.

Shahid, H., Xia, X., Mahmood, F. and Usman, M. 2010. Behaviour of Information Asymmetry During SEOs Issue Process: Evidence From China. Asian Journal of Management Research.

Scholes, M. S. 1972. The Market for Securities: Substitution versus Price Pressure and the Effects of Information on Share Prices. The Journal of Business. 45(2): 179 - 211.

Shen, Y. 2006. Seasoned Equity Offerings : Evidence From P.R. China. Master Thesis. Concordia University, Montreal Canada.

Wruck, K. 1989. Equity ownership concentration and firm value : Evidence from private equity financings. Journal of Financial Economics. 23(1): $3-28$

Wu, X., Wang, Z and Yao, J. 2005. Understanding the Positive Announcement Effects of the Private Equity Placements: New Insights from Hong Kong Data. Review of Finance. 9(3): $385-414$. 